\title{
Ouabain suppresses the growth and migration abilities of glioma U-87MG cells through inhibiting the Akt/mTOR signaling pathway and downregulating the expression of HIF-1 $\alpha$
}

\author{
XIAO-SA YANG ${ }^{1 *}$, ZHONG-WEI XU $^{2 *}$, TAI-LONG YI ${ }^{1 *}$, RUI-CHENG XU $^{3 *}$, JIE LI $^{1}$, WEN-BIN ZHANG ${ }^{1}$, \\ SAI ZHANG ${ }^{1}$, HONG-TAO SUN ${ }^{1}$, ZE-QI YU ${ }^{1}$, HAO-XIANG XU ${ }^{1}$, YUE TU ${ }^{1}$ and SHI-XIANG CHENG ${ }^{1}$ \\ ${ }^{1}$ Institute of TBI and Neuroscience of Chinese People's Armed Police Force, Tianjin Key Laboratory of Neurotrauma Repair, \\ Center for Neurology and Neurosurgery of Affiliated Hospital of Logistics University of PAP, Tianjin 300162; \\ ${ }^{2}$ Central Laboratory of Logistics University of PAP; ${ }^{3}$ Tianjin Key Laboratory for Biomarkers of Occupational \\ and Environmental Hazard, Logistics University of PAP, Tianjin 300309, P.R. China
}

Received September 30, 2016; Accepted June 5, 2017

DOI: $10.3892 / \mathrm{mmr} .2018 .8587$

\begin{abstract}
Glioma is one of the most malignant forms of brain tumor, and has been of persistent concern due to its high recurrence and mortality rates, and limited therapeutic options. As a cardiac glycoside, ouabain has widespread applications in congestive heart diseases due to its positive cardiac inotropic effect by inhibiting $\mathrm{Na}^{+} / \mathrm{K}^{+}$-ATPase. Previous studies have demonstrated that ouabain has antitumor activity in several types of human tumor, including glioma. However, the exact underlying mechanism remains to be elucidated. The purpose of present study was to elucidate the effect of ouabain on human glioma cell apoptosis and investigate the exact mechanism. $\mathrm{U}-87 \mathrm{MG}$ cells were treated with various concentrations of ouabain for $24 \mathrm{~h}$, following which cell viability and survival rate were assessed using a 3-(4,5-dimethylthiazol-2-yl)-2,5-diphenyltetrazolium bromide assay. The dynamic changes and cell motility were observed using digital holographic microscopy. Additionally, western blot analysis and high-content screening assays were used to detect the protein expression levels of phosphorylated (p-)Akt, mammalian target of rapamycin
\end{abstract}

Correspondence to: Professor Yue Tu or Professor Shi-Xiang Cheng, Institute of TBI and Neuroscience of Chinese People's Armed Police Force, Tianjin Key Laboratory of Neurotrauma Repair, Center for Neurology and Neurosurgery of Affiliated Hospital of Logistics University of PAP, 220 Chenglin Road, Hedong, Tianjin 300162, P.R. China

E-mail: ytumail@vip.126.com

E-mail: shixiangcheng@vip.126.com

${ }^{*}$ Contributed equally

Abbreviations: FBS, fetal bovine serum; DHM, digital holographic microscopy; HCS, high-content screening

Key words: ouabain, glioblastoma, U-87MG cells, Akt/mammalian target of rapamycin signaling pathway, hypoxia-inducible factor-1 $\alpha$
(mTOR), p-mTOR and hypoxia-inducible factor (HIF)-1 $\alpha$, respectively. Compared with the control group, ouabain suppressed U-87MG cell survival, and attenuated cell motility in a dose-dependent manner $(\mathrm{P}<0.01)$. The downregulation of p-Akt, mTOR, p-mTOR and HIF-1 $\alpha$ were observed following treatment with 2.5 and $25 \mu \mathrm{mol} / 1$ of ouabain. These results suggested that ouabain exerted suppressive effects on tumor cell growth and motility, leading to cell death via regulating the intracellular Akt/mTOR signaling pathway and inhibiting the expression of HIF-1 $\alpha$ in glioma cells. The present study examined the mechanism underlying the antitumor property of ouabain, providing a novel potential therapeutic agent for glioma treatment.

\section{Introduction}

Gliomas are serious primary brain tumors, which account for $80 \%$ of malignant tumors of the central nervous system in the United States. Current therapeutic strategies for this type of brain cancer are inadequate and the median survival rate for patients with malignant glioma is 14 months due to their aggressive nature, high recurrence rate, and gradual increase in radiotherapy and chemotherapy resistance (1). Therefore, it is vital to examine the mechanisms underlying the progression of glioma and to urgently develop novel therapies with improved therapeutic effects for the treatment of patients with glioma.

Ouabain is a steroid, which is extracted from the seeds and leaves of digitalis (2). As a cardiac glycoside, ouabain is used in the treatment of congestive heart disease due to its positive cardiac inotropic effect by inhibiting $\mathrm{Na}^{+} / \mathrm{K}^{+}$-ATPase or $\mathrm{Na}^{+} / \mathrm{K}^{+}$ pumps and increasing intracellular calcium (3). Previous studies have shown that the plasma transporter, $\mathrm{Na}^{+} / \mathrm{K}^{+}$-ATPase, which is the unique receptor established for ouabain, not only functions as an ion pump, but is overexpressed in different types of tumor, including lung cancer, hepatoma and gliomas (4-6), and its inhibitors are concerned with the regulation of multiple intracellular signaling pathways, including Akt/mammalian target of rapamycin (mTOR), Ras and protein kinase C (PKC) (7). 
Previous studies have reported that, as a specific $\mathrm{Na}^{+} / \mathrm{K}^{+}$-ATPase inhibitor, ouabain may affect the adhesion and metastasis of tumor cells, resulting in the apoptosis of several tumor cells, including malignant breast cancer, prostate cancer and human leukemia (8). In addition, epidemiological evidence shows that tumor patients treated with cardiac glycosides have lower mortality rates, compared with those treated without cardiac glycosides, suggesting that ouabain has potential antitumor effects (9). However, the mechanism underlying its antitumor effect remains to be elucidated.

In the present study, the human glioblastoma U-87MG cell line was selected to examine the effects of ouabain, as a specific $\mathrm{Na}^{+} / \mathrm{K}^{+}$-ATPase inhibitor, on the apoptosis of U87-MG cells, followed by preliminarily investigation of the role of the Akt/mTOR signaling pathway in the process.

\section{Materials and methods}

Materials. Dulbecco's modified Eagle's medium (DMEM) and fetal bovine serum (FBS) were obtained from Gibco; Thermo Fisher Scientific, Inc. (Waltham, MA, USA). Ouabain was purchased from Sigma-Aldrich (Merck KGaA, Darmstadt, Germany). 3-(4,5-dimethylthiazol-2-yl)-2,5-diphenyltetrazolium bromide (MTT) was purchased from (Promega Corporation, Madison, WI, USA).

Cell culture and grouping. The human U-87MG glioma cell line was obtained from the American Type Culture Collection (Mannasas, VA, USA) and cultured in DMEM containing 10\% FBS and $1 \%$ penicillin/streptomycin in a humidified incubator of $5 \% \mathrm{CO}_{2}$ at $37^{\circ} \mathrm{C}$. The cells were randomized into two groupings: Ouabain-treated groups $(0.05,0.25,0.5,2.5,5$ and $25 \mu \mathrm{mol} / 1$ for the MTT assay; 0.05, 0.5, 2.5 and $25 \mu \mathrm{mol} / 1$ for other experiments) and a control group (cultured with an equal volume of culture medium containing $0.1 \%$ DMSO).

MTT assay. For the MTT assays, $4 \times 10^{3}$ cells were seeded into each well of 96-well plates. Following conventional culture for $24 \mathrm{~h}, 200 \mu \mathrm{l}$ of the different concentrations of ouabain were added into each well and the cells were cultured for another $24 \mathrm{~h}$ at $37^{\circ} \mathrm{C}$. In the control group, the cells were cultured in $200 \mu \mathrm{l}$ of culture medium containing $0.1 \%$ DMSO only. Following culture, $10 \mu \mathrm{l}$ of $5 \mathrm{mg} / \mathrm{ml}$ MTT was added to the cells in each well and incubated for $4 \mathrm{~h}$. Subsequently, $150 \mu \mathrm{l}$ of DMSO (150 $\mu \mathrm{l})$ was added for $10 \mathrm{~min}$ and the plates were positioned in a microplate autoreader (Thermo Fisher Scientific, Inc.) The optical density at $490 \mathrm{~nm}$ wavelength was read. On the basis of the optical density (A value), cell viability was calculated as follows: Cell viability=average $A$ value of ouabain-treated cells/average $A$ value of control $x 100 \%$. The half maximal inhibitory concentration $\left(\mathrm{IC}_{50}\right)$ value was calculated as the concentration required for $50 \%$ inhibition of cell growth.

Digital holographic microscopy (DHM) assay. The DHM (HoloMonitor $^{\mathrm{TM}}$ M4; Phase Holographic Imaging AB, Lund, Sweden) was used to record the 3D structure of adherent cells via interfering wave front induction when exposed to the $0.8 \mathrm{~mW}$ HeNe laser $(633 \mathrm{~nm})$. The DHM was based on measurements of how the cells shift light, which passes through the cells without any labeling or staining. The cells were plated in 6-well plates at $1 \times 10^{5} / \mathrm{ml}$ and cultured for $24 \mathrm{~h}$, following which different concentrations of ouabain were added into each well prior to being moved to the DHM. This was placed in an incubator and was used to capture time-lapse images of the 6-well plates at 5 min intervals for $24 \mathrm{~h}$. For each sample, a region for imaging was randomly selected and changes in cell number were analyzed using HoloStudio 2.6.2 software (Holographic Imaging AB). In addition, 10 cells were randomly selected per well to perform cell motion tracking, and cell motility was determined as the distance of cell movement throughout the $24 \mathrm{~h}$ of time-lapse video.

Protein extraction and western blot analysis. Following treatment with $0.05,0.5,2.5$ and $25 \mu \mathrm{mol} / \mathrm{l}$ of ouabain for $24 \mathrm{~h}$, the cells were rinsed in ice-cold PBS three times, collected with a cell scraper, and lysed in lysis buffer containing $50 \mathrm{mmol} / 1$ Tris- $\mathrm{HCl}$ (pH 7.2), $250 \mathrm{mmol} / 1 \mathrm{NaCl}, 0.1 \% \mathrm{NP}-40,2 \mathrm{mmol} / \mathrm{l}$ EDTA, $10 \%$ glycerol, $1 \mathrm{mmol} / 1 \mathrm{PMSF}, 5 \mu \mathrm{g} / \mathrm{ml}$ aprotinin and $5 \mu \mathrm{g} / \mathrm{ml}$ leupeptin on ice. The concentrations of the proteins of interest were quantified using the BCA method. Protein samples $(40 \mu \mathrm{g})$ of each group were separated by $10 \%$ polyacrylamide gel electrophoresis and transferred onto nitrocellulose membranes, which were blocked at room temperature by $5 \%$ nonfat milk for $1 \mathrm{~h}$. The membranes were then incubated with primary antibodies including Akt (ab179463, 1:1,000; Abcam, Cambridge, MA, USA), p-Akt (ab81283, 1:1,000; Abcam, Cambridge, MA, USA), mTOR (ab32028, 1:1,000; Abcam), p-mTOR (ab109268, 1:1,000; Abcam) and HIF-1 $\alpha$ (ab51608, 1:1,000; Abcam) overnight at $4^{\circ} \mathrm{C}$ and were subsequently incubated with secondary antibody (anti-rabbit IgG; 5210-0174; 1:5,000; KPL, Inc., Gaithersburg, $\mathrm{MD}, \mathrm{USA}$ ) for $2 \mathrm{~h}$ at room temperature. $\beta$-actin was used as the internal control for protein loading.

High-content screening (HCS) assay. The cells were seeded in 96-well plates at $2 \times 10^{5} /$ well, cultured for $24 \mathrm{~h}$, and treated with different concentrations of ouabain added into each well. The cells were then fixed with $4 \%$ paraformaldehyde and permeabilized with $0.25 \%$ Triton-X 100 . The fixed cells were nonspecifically blocked in 5\% nonfat milk for $1 \mathrm{~h}$ and incubated with primary antibodies (Akt, p-Akt, mTOR, p-mTOR, and $\mathrm{HIF}-1 \alpha$ ) at 1:1,000 dilution overnight at $4^{\circ} \mathrm{C}$. Following incubation, the cells were stained with FITC-labeled anti-rabbit IgG secondary antibody (5230-0298; 1:200 dilution; KPL, Inc., Gaithersburg, MD, USA) for $1 \mathrm{~h}$ at room temperature, and $1 \mathrm{~g} / \mathrm{ml}$ of DAPI for $10 \mathrm{~min}$. The immunofluorescence of the stained cells was quantified using the HCA cell analyzer 2200 (GE Healthcare Life Sciences, Chalfont, UK).

Statistical analysis. SPSS 13.0 statistical software (SPSS, Inc., Chicago, IL, ISA) was used for data analysis. All data are expressed as the mean \pm standard deviation and were analyzed using one-way analysis of variance followed Tukey's post hoc analysis. $\mathrm{P}<0.05$ was considered to indicate a statistically significant difference.

\section{Results}

Ouabain suppresses the viability of $U-87 M G$ cells. To assess the effect of ouabain on U-87MG cells, the cultured U-87MG 


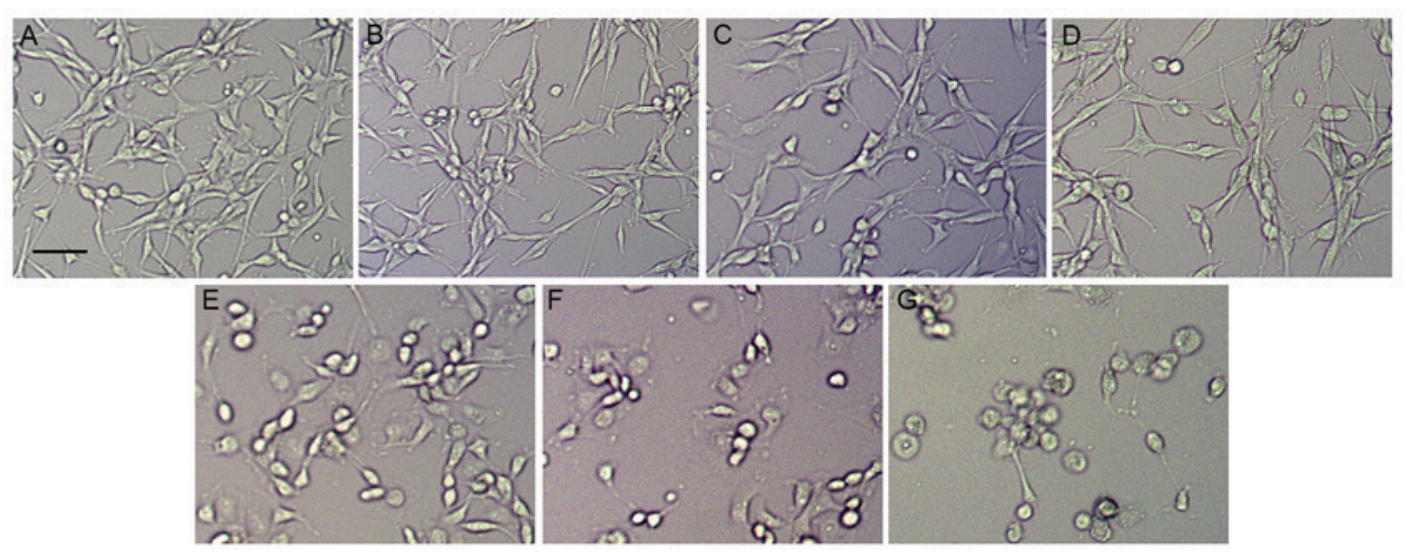

Figure 1. Phase contrast microscopy of morphological changes in U-87MG cells treated with ouabain. Cells were treated with different concentrations of ouabain for $24 \mathrm{~h}$. (A) Control group. (B) $0.05 \mu \mathrm{mol} / 1$ ouabain, (C) $0.25 \mu \mathrm{mol} / 1$ ouabain, (D) $0.5 \mu \mathrm{mol} / 1$ ouabain, (E) $2.5 \mu \mathrm{mol} / 1$ ouabain (F) $5 \mu \mathrm{mol} / 1$ ouabain and (G) $25 \mu \mathrm{mol} / 1$ ouabain. Scale bar $=200 \mu \mathrm{m}$.

A

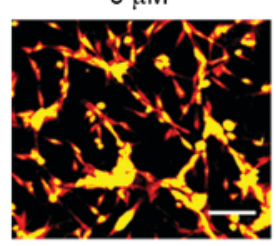

B

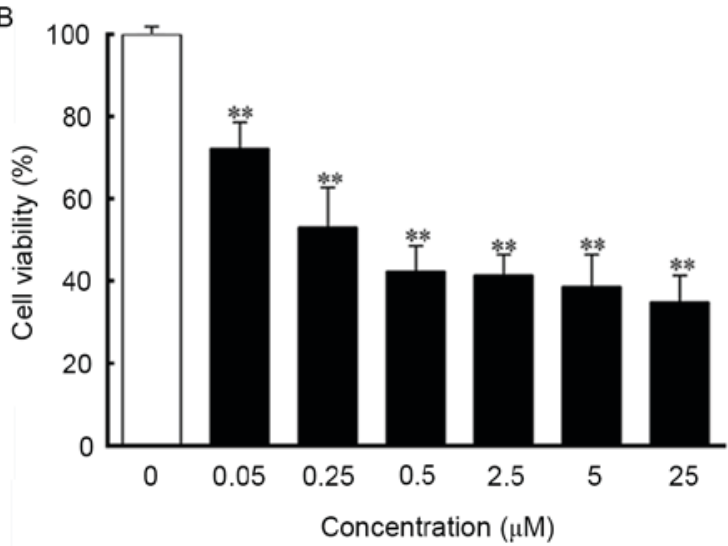

$0.05 \mu \mathrm{M}$
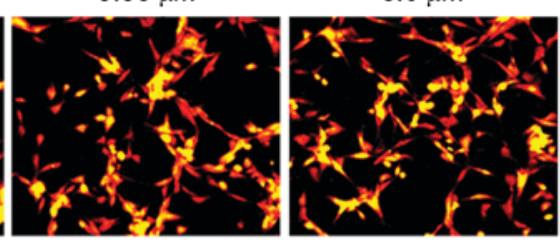

$2.5 \mu \mathrm{M}$

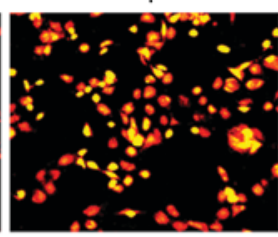

C

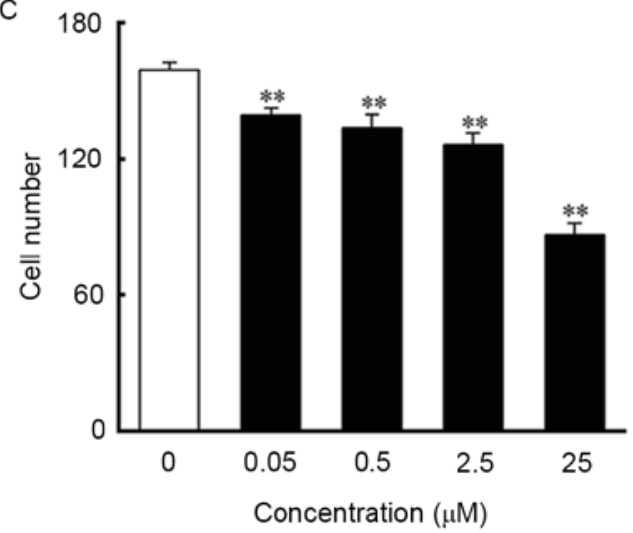

Figure 2. Ouabain suppresses U-87MG cell growth. Cells were incubated with different concentrations of ouabain for 24 h. (A) Time-lapse images were captured using a digital hologram microscope. Scale bar=100 $\mu \mathrm{m}$. (B) Cell viability was determined as the percentage of cells, compared with those in the control culture. (C) Cell numbers were analyzed using HoloStudio 2.6 .2 software. ${ }^{* *} \mathrm{P}<0.01$, vs. control group.

cells were exposed to different concentrations of ouabain for $24 \mathrm{~h}$. The U-87MG cells in the control group exhibited orderly shapes, well-defined borders and satisfactory diopter. By contrast, the cells treated with increasing concentrations of ouabain gradually shrunk, and exhibited poorly defined margins and irregular shapes, with cell death observed (Fig. 1A-G). As shown in Fig. 2A, the control cells grew into clusters with a normal morphology, whereas the cells treated with ouabain exhibited increasing shrinkage as the concentration of ouabain increased. The results of the MTT assay indicated that the viability of cells treated with ouabain were significantly decreased and in a dose-dependent manner, compared with those in the control group. The $\mathrm{IC}_{50}$ of ouabain treatment for $24 \mathrm{~h}$ was $0.45 \mu \mathrm{mol} / \mathrm{l}$ (Fig. 2B). The analysis of cell numbers suggested that ouabain treatment decreased the number of cells in a dose-dependent manner, which was in line with the morphological changes and the MTT results (Fig. 2C).

Ouabain inhibits the motility of $U-87 M G$ cells. In order to investigate whether U-87MG cell motility was reduced under ouabain treatment, compared with controls, time-lapse videos were used to assess real-time cell motility, and cell displacement in the control and under different concentrations of ouabain were tracked. The cell motion tracking indicated that, following treatment with ouabain for $24 \mathrm{~h}$, the movement range of U-87MG cells was decreased as the concentration of ouabain increased, and the routes of selected cells were irregular and multidirectional (Fig. 3A). Compared with the control $(919 \pm 79 \mu \mathrm{m})$, the migration ability of the U-87MG cells in $0.5,2.5$ and $25 \mu \mathrm{mol} / 1$ ouabain treatment groups were suppressed in a dose-dependent manner $(0.5 \mu \mathrm{mol} / 1$, 

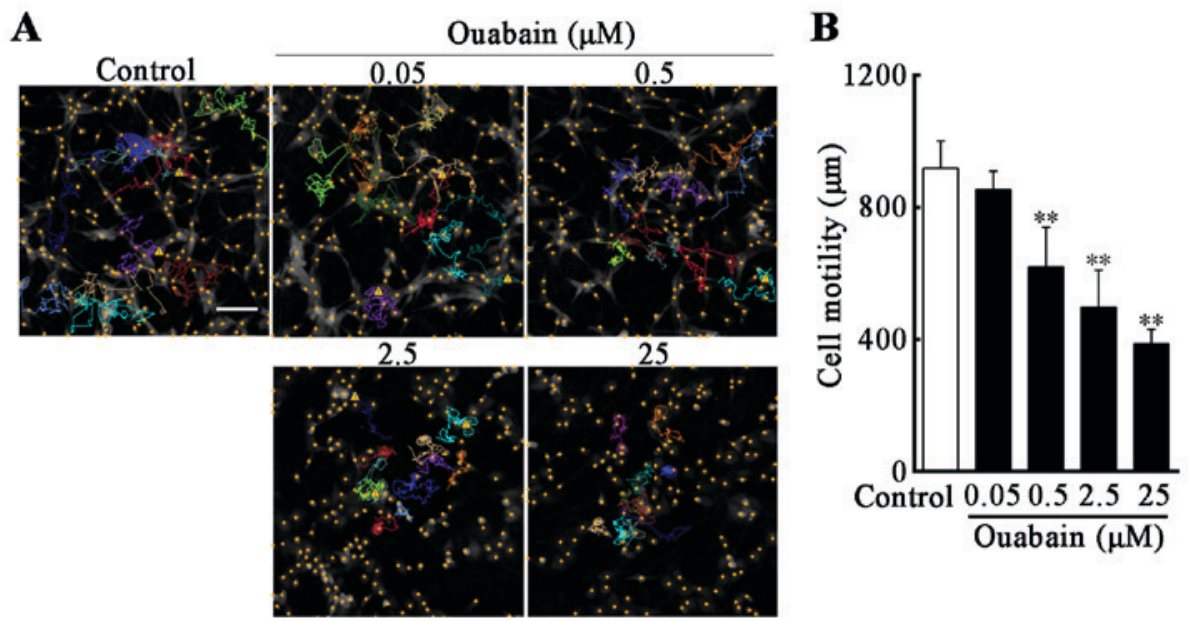

Figure 3. Inhibition of U-87MG cell motility is induced by ouabain. Cells were treated with the indicated concentrations of ouabain for $24 \mathrm{~h}$. (A) Motion tracking of selected cells in the imaging area was performed using HoloStudio 2.6.2 software. The curved colored lines represent the moving path of selected wells during $24 \mathrm{~h}$ treatment and the yellow cross dots indicate cell nuclei in the imaging field. (B) Cell motility was measured as the distance of cell movement throughout the $24 \mathrm{~h}$ time-lapse video and analyzed using HoloStudio 2.6.2 software. Scale bar=100 $\mu \mathrm{m}$. ${ }^{* *} \mathrm{P}<0.01$, vs. control group.
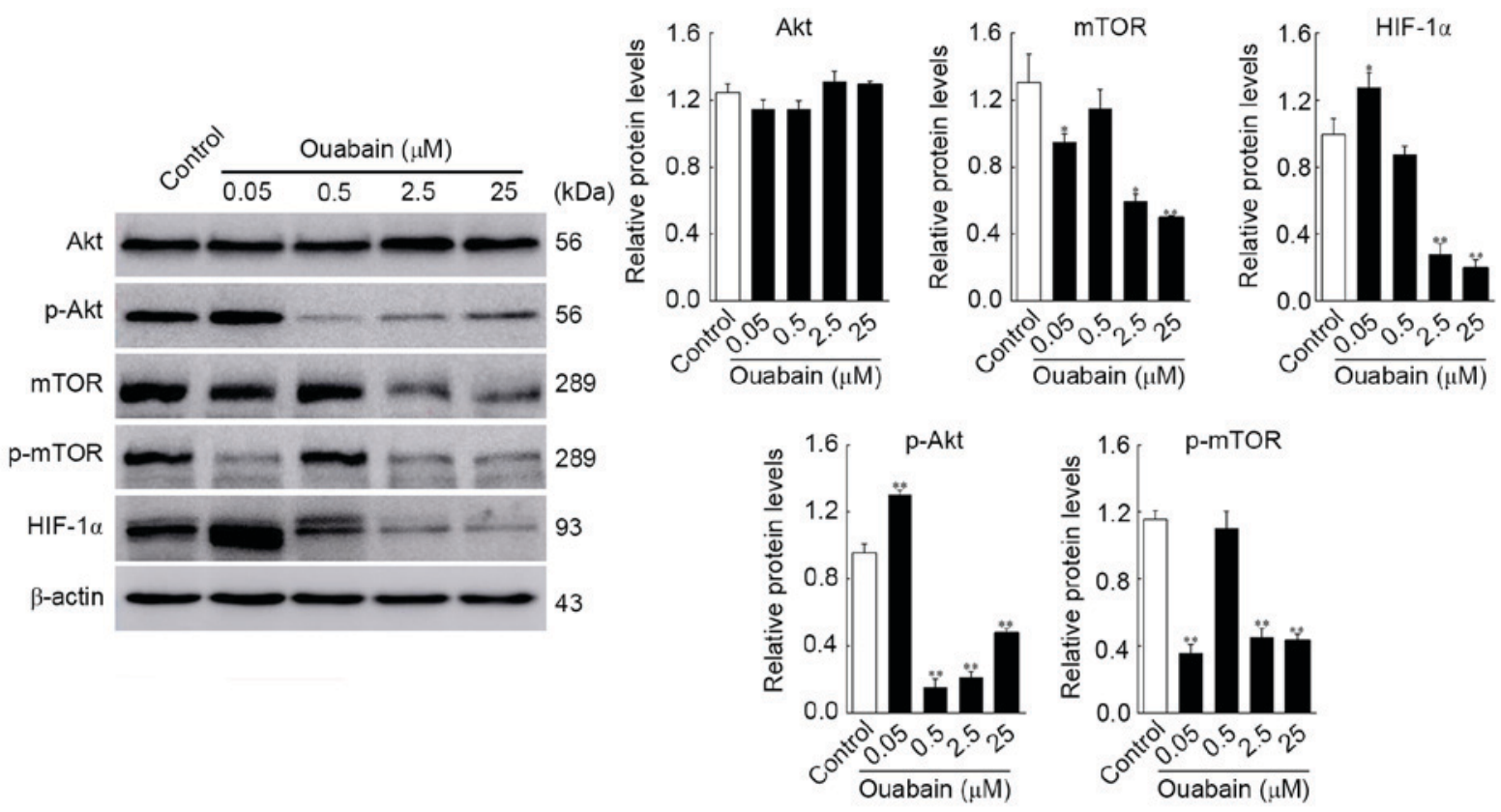

Figure 4. Changes in expression levels of Akt, p-Akt, mTOR, p-mTOR and HIF-1 $\alpha$ in U-87MG cells are induced by ouabain. Cells were treated with the different concentrations of ouabain for $24 \mathrm{~h}$, following which protein expression was analyzed using western blot analysis and quantified in relation to $\beta$-actin. ${ }^{*} \mathrm{P}<0.05$ and ${ }^{* *} \mathrm{P}<0.01$, vs. control group. mTOR, mammalian target of rapamycin; $\mathrm{p}-$, phosphorylated; HIF-1 $\alpha$, hypoxia inducible factor-1 $\alpha$.

$620 \pm 115 \mu \mathrm{m} ; 2.5 \mu \mathrm{mol} / 1,498 \pm 107 \mu \mathrm{m} ; 25 \mu \mathrm{mol} / 1,387 \pm 42 \mu \mathrm{m}$; $\mathrm{P}<0.01$; Fig. 3B).

Ouabain affects the expression of Akt/mTOR signaling pathway proteins. It has been shown that the survival and proliferation of glioma cells can be enhanced by activation of the Akt/mTOR signaling pathway, which has been targeted for glioma treatment (10). To obtain additional evidence for the ouabain-inhibited viability and motility of U-87MG cells, the expression of Akt/mTOR signaling pathway regulators were analyzed using western blot analysis and HCS. As shown in Fig. 4, the protein expression levels of p-Akt and HIF- $1 \alpha$ in the $0.05 \mu \mathrm{mol} / 1$ ouabain-treated group was significantly altered, compared with that in the control group (p-Akt, 1.30 \pm 0.02 , vs. 0.96 $\pm 0.04, \mathrm{P}<0.01$; HIF-1 $\alpha, 1.32 \pm 0.24$, vs. $1.06 \pm 0.16, \mathrm{P}<0.05$; ), whereas that of mTOR and $\mathrm{p}-\mathrm{mTOR}$ decreased rapidly (mTOR, $0.95 \pm 0.04$, vs. $1.31 \pm 0.13, \mathrm{P}<0.05$; p-mTOR, $0.36 \pm 0.04$, vs. $1.16 \pm 0.04, \mathrm{P}<0.01)$. Treatment with $0.5 \mu \mathrm{mol} / \mathrm{l}$ ouabain reduced only the expression of $\mathrm{p}-\mathrm{Akt}$ $(0.15 \pm 0.04$, vs. $0.96 \pm 0.04, \mathrm{P}<0.01)$. In addition, the expression levels of Akt, mTOR, p-mTOR and HIF-1 $\alpha$ were decreased by 2.5 and $25 \mu \mathrm{mol} / 1$ ouabain: p-Akt, $0.21 \pm 0.02$ and $0.48 \pm 0.02$, vs. $0.96 \pm 0.04 ; \mathrm{mTOR}, 0.60 \pm 0.03$ and $0.50 \pm 0.01$, vs $1.31 \pm 0.14$; p-mTOR, $0.45 \pm 0.04$ and $0.43 \pm 0.03$, vs. $1.16 \pm 0.04$; HIF- $1 \alpha, 0.28 \pm 0.05$ and $0.20 \pm 0.04$, vs. $1.06 \pm 0.16(\mathrm{P}<0.05$ or $\mathrm{P}<0.01)$. However, no significant differences were found 
in the expression of Akt following treatment with ouabain $(\mathrm{P}>0.05)$. These results were corroborated by HCS assays (Fig. 5). Therefore, it was hypothesized that ouabain mediated the suppression of U-87MG cell viability and motility via downregulating proteins of the Akt/mTOR signaling pathway.

\section{Discussion}

There has been important progress in therapeutic strategies for gliomas in previous decades, as one of the most malignant types of brain tumor with high relapse and mortality rates. In the present study, ouabain intervention of glioma U-87MG cells was performed for the experimental investigation of therapeutic strategies for glioma, as U-87MG cells are more susceptible to cardiac glycosides, and ouabain can cross the blood brain barrier as a liquid, soluble cardiac glycoside.

$\mathrm{Na}^{+} / \mathrm{K}^{+}$-ATPase comprises an $\alpha$ subunit and $\beta$ subunit, and the $\alpha$ subunit, which is essential in the transport activity of $\mathrm{Na}^{+} / \mathrm{K}^{+}$-ATPase, contains multiple binding sites of ATP and the enzyme inhibitor ouabain (11). Increasing evidence suggests that $\mathrm{Na}^{+} / \mathrm{K}^{+}$-ATPase is essential in the regulation of ion homeostasis and formation of the pathogenesis of glioma. Ahmed et al (12) reported that the inhibition of $\mathrm{Na}^{+} / \mathrm{K}^{+}$-ATPase regulated cell adhesion and migration, inhibited intracellular PKC and the $\mathrm{NF}-\kappa \mathrm{B}$ signaling pathway, and consequently resulted in the apoptosis of tumor cells. Additionally, Lin et al (13) found that ouabain inhibited the $\alpha$-subunit activity of $\mathrm{Na}^{+} / \mathrm{K}^{+}$-ATPase, suppressed tumor cell growth, and eventually caused tumor cell death. The present study revealed that ouabain intervention inhibited U-87MG cell viability and cell motility in a dose-dependent manner, suggesting that ouabain promoted the apoptosis of U87-MG cells, which may be associated with alterations in certain intracellular signaling pathways.

In previous years, there has been an improved understanding of the role of $\mathrm{Na}^{+} / \mathrm{K}^{+}$-ATPase in multiple signaling pathways, including $\mathrm{Akt} / \mathrm{mTOR}$, Ras and $\mathrm{PKC}$, resulting in the promotion of tumor invasion and metastasis (14). Notably, the Akt/mTOR signaling pathway is crucial for tumor progression according to the regulation of cell survival, proliferation, invasion and stem cell function (15). The upregulation of Akt/mTOR can directly or indirectly inhibit the phosphorylation of B-cell lymphoma 2-associated X protein, caspase- 9 and other apoptosis-associated proteins, which attenuates apoptosis and leads to the deterioration of physiological functions (16). Liu et al (17) confirmed the effect of inhibition of the Akt/mTOR pathway against apoptosis in glioma; the pharmacological suppression of Akt/mTOR and their phosphorylation upregulates downstream proteins correlated with apoptosis, inducing an increase in the apoptosis of tumor cells.

Previous studies have confirmed that ouabain depresses the phosphorylation of Akt and mTOR via regulating phosphoinositide 3-kinase (PI3K), Ras and PKC signaling pathways, which causes cell growth depression and the enhancement of apoptosis (13). In the present study, it was found that the phosphorylation of Akt and mTOR significantly reduced cell viability, survival rate and cell mobility when treated with 2.5 and $25 \mu \mathrm{mol} / 1$ of ouabain, which confirmed that the antitumor property of ouabain involved the alteration of certain intracellular signaling pathways.

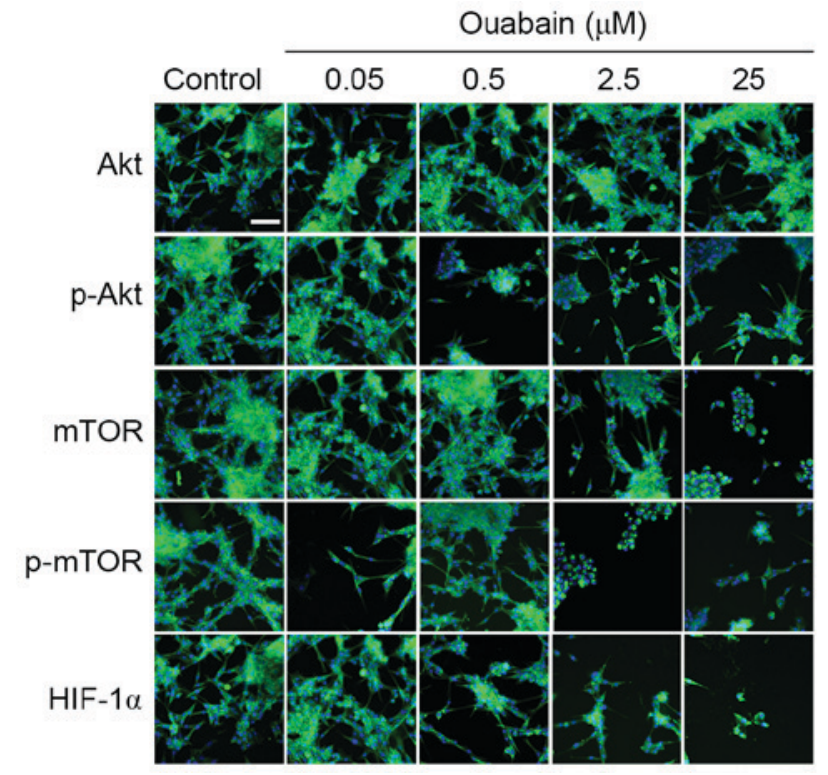

Figure 5. High content screening analyses of the changes in protein levels treated with ouabain. U-87MG cells were treated with the different concentrations of ouabain for $24 \mathrm{~h}$ and fluorescence images were captured. Scale bar $=50 \mu \mathrm{m}$. mTOR, mammalian target of rapamycin; $\mathrm{p}-$, phosphorylated; HIF-1 $\alpha$, hypoxia inducible factor- $1 \alpha$.

The overexpression of HIF-1 $\alpha$ has been reported in several types of human tumor and metastasis, including glioma, which is closely associated with tumor invasion and metastasis, resistance to chemotherapy and radiotherapy, and poor prognosis (18). As an important regulator in hypoxic microenvironments, resulting from insufficient oxygen and nutrient supply for rapidly growing tumors, the activation of HIF-1 $\alpha$ promotes tumor adaption to hypoxia through the promotion of cell survival, motility and angiogenesis $(19,20)$. Soeda et al (21) demonstrated that the hypoxic induction of HIF-1 $\alpha$ facilitated the self-renewal and proliferation of glioma stem cells, and maintained glioma stem cells in an undifferentiated state with multilineage potential. This assisted in glioma progression and metastasis.

In addition, previous studies have documented that the Akt/mTOR pathway is associated with hypoxia signaling transduction. The phosphorylation of Akt and mTOR can intensify the hypoxic induction of HIF-1 $\alpha$ at the translational level, and promotes the stabilization and activation of HIF-1 $\alpha$, which regulates intracellular glucose utilization and angiogenesis, eventually promoting the growth of tumor cells $(19,22)$. García-Maceira and Mateo demonstrated that inhibiting the phosphorylation of Akt and mTOR occurred with loss of the expression of HIF-1 $\alpha$, whereas inhibition of the Akt/mTOR pathway decreased the translation of HIF-1 $\alpha$ and ultimately led to apoptosis of tumor cells (23). Consistently, the present study demonstrated that the downregulation of HIF-1 $\alpha$ was simultaneous with the reduced phosphorylation of Akt and mTOR at high concentrations of ouabain $(2.5$ and $25 \mu \mathrm{mol} / \mathrm{l})$, suggesting that the regulation of HIF-1 $\alpha$ by the Akt/mTOR pathway was involved in tumor suppressive effect of ouabain.

In conclusion, the data obtained in the present study suggested that high concentrations of ouabain may depress human glioma U-87MG cell growth, attenuate cell mobility and lead to apoptosis via inhibiting the intracellular Akt/mTOR 
pathway and associated HIF-1 $\alpha$. These data identify ouabain as a potential target for the treatment of glioma in the future.

\section{Acknowledgements}

Not applicable.

\section{Funding}

This study was supported by grants from the Tianjin Natural Science Foundation (grant no. 17JCYBJC25700 and 15ZXLCSY00040), the National Natural Science Foundation of China (grant nos. 31200809, 81273552 and 81673651) and the Open Research Funding Program from Logistics University of PAP (grant no. 2015ZXKF09).

\section{Availability of data and materials}

All data generated or analyzed during this study are included in this published article.

\section{Authors' contributions}

XSY, ZWX, TLY, YT and SXC conceived and designed the study. XSY, ZWX and TLY performed the experiments; RCX, JL, WBZ, SZ, HTS and ZQY analyzed the results. XSY and SXC wrote the paper. XSY, ZWX and TLY contributed equally to this study. Co-corresponding authors of YT and SXC contributed equally to this study. All authors reviewed and approved the final manuscript.

\section{Ethics approval and consent to participate}

Not applicable.

\section{Consent for publication}

Not applicable.

\section{Competing interests}

All authors declared that they have no competing interests.

\section{References}

1. Jain A, Lai JC and Bhushan A: Biochanin A inhibits endothelia cell functions and proangiogenic pathways: Implications in glioma therapy. Anticancer Drugs 26: 323-330, 2015.

2. Bagrov AY, Shapiro JI and Fedorova OV: Endogenous cardiotonic steroids: Physiology, pharmacology, and novel therapeutic targets. Pharmacol Rev 61: 9-38, 2009.

3. Kulikov A, Eva A, Kirch U, Boldyrev A and Scheiner-Bobis G: Ouabain activates signaling pathways associated with cell death in human neuroblastoma. Biochim Biophys Acta 1768: 1691-1702, 2007.

4. Kim N, Yim HY, He N, Lee CJ, Kim JH, Choi JS, Lee HS, Kim S, Jeong E, Song M, et al: Cardiac glycosides display selective efficacy for STK11 mutant lung cancer. Sci Rep 6: 29721, 2016.

5. Xu Z, Wang F, Fan F, Gu Y, Shan N, Meng X, Cheng S, Liu Y, Wang $\mathrm{C}$, Song $\mathrm{Y}$ and $\mathrm{Xu} \mathrm{R}$ : Quantitative proteomics reveals that the inhibition of $\mathrm{Na}^{+} / \mathrm{K}^{+}$-ATPase activity affects S-phase progression leading to a chromosome segregation disorder by attenuating the Aurora A function in hepatocellular carcinoma cells. J Proteome Res 14: 4594-4602, 2015.
6. Yan X, Liang F, Li D and Zheng J: Ouabain elicits human glioblastoma cells apoptosis by generating reactive oxygen species in ERK-p66SHC-dependent pathway. Mol Cell Biochem 398: 95-104, 2015.

7. Zhang L, Zhang Z, Guo $\mathrm{H}$ and Wang $\mathrm{Y}: \mathrm{Na}^{+} / \mathrm{K}^{+}$-ATPase-mediated signal transduction and $\mathrm{Na}^{+} / \mathrm{K}^{+}-$ATPase regulation. Fundam Clin Pharmacol 22: 615-621, 2008.

8. Desfrere L, Karlsson M, Hiyoshi H, Malmersjö S, Nanou E, Estrada M, Miyakawa A, Lagercrantz H, El Manira A, Lal M and Uhlén P: Na, K-ATPase signal transduction triggers CREB activation and dendritic growth. Proc Natl Acad Sci USA 106: 2212-2217, 2009.

9. Prassas I and Diamandis EP: Novel therapeutic applications of cardiac glycosides. Nat Rev Drug Discov 7: 926-935, 2008.

10. Wei L, Su YK, Lin CM, Chao TY, Huang SP, Huynh TT, Jan HJ, Whang-Peng J, Chiou JF, Wu AT and Hsiao M: Preclinical investigation of ibrutinib, a Bruton's kinase tyrosine (Btk) inhibitor, in suppressing glioma tumorigenesis and stem cell phenotypes. Oncotarget 7: 69961-69975, 2016.

11. Xie Z: Molecular mechanisms of $\mathrm{Na} / \mathrm{K}-\mathrm{ATPase}-$ mediated signal transduction. Ann N Y Acad Sci 986: 497-503, 2003.

12. Ahmed Z, Deyama Y, Yoshimura Y and Suzuki K: Cisplatin sensitivity of oral squamous carcinoma cells is regulated by $\mathrm{Na}^{+}, \mathrm{K}^{+}$-ATPase activity rather than copper-transporting P-type ATPases, ATP7A and ATP7B. Cancer Chemother Pharmacol 63: 643-650, 2009.

13. Lin Y, Ho DH and Newman RA: Human tumor cell sensitivity to oleandrin is dependent on relative expression of $\mathrm{Na}^{+}, \mathrm{K}^{+}$-ATPase subunitst. J Exp Ther Oncol 8: 271-286, 2010.

14. Wu J, Akkuratov EE, Bai Y, Gaskill CM, Askari A and Liu L: Cell signaling associated with $\mathrm{Na}^{+} / \mathrm{K}^{+}$-ATPase: Activation of phosphatidylinositide 3-kinase IA/Akt by ouabain is independent of Src. Biochemistry 52: 9059-9067, 2013.

15. Joy A, Kapoor M, Georges J, Butler L, Chang Y, Li C, Crouch A, Smirnov I, Nakada M, Hepler J, et al: The role of AKT isoforms in glioblastoma: AKT3 delays tumor progression. J Neurooncol 130: 43-52, 2016.

16. Clark PA, Bhattacharya S, Elmayan A, Darjatmoko SR, Thuro BA, Yan MB, van Ginkel PR, Polans AS and Kuo JS: Resveratrol targeting of AKT and p53 in glioblastoma and glioblastoma stem-like cells to suppress growth and infiltration. J Neurosurg 126: 1448-1460, 2017.

17. Liu Y, Zheng J, Zhang Y, Wang Z, Yang Y, Bai M and Dai Y: Fucoxanthin activates apoptosis via inhibition of PI3K/Akt/ mTOR pathway and suppresses invasion and migration by restriction of p38-MMP-2/9 pathway in human glioblastoma cells. Neurochem Res 41: 2728-2751, 2016.

18. Rapisarda A, Uranchimeg B, Sordet O, Pommier Y, Shoemaker RH and Melillo G: Topoisomerase I-mediated inhibition of hypoxia-inducible factor 1: Mechanism and therapeutic implications. Cancer Res 64: 1475-1482, 2004.

19. Thomas GV, Tran C, Mellinghoff IK, Welsbie DS, Chan E, Fueger B, Czernin J and Sawyers CL: Hypoxia-inducible factor determines sensitivity to inhibitors of mTOR in kidney cancer. Nat Med 12: 122-127, 2006.

20. Jensen RL, Ragel BT, Whang K and Gillespie D: Inhibition of hypoxia inducible factor-1alpha (HIF-1alpha) decreases vascular endothelial growth factor (VEGF) secretion and tumor growth in malignant gliomas. J Neurooncol 78: 233-247, 2006.

21. Soeda A, Park M, Lee D, Mintz A, Androutsellis-Theotokis A, McKay RD, Engh J, Iwama T, Kunisada T, Kassam AB, et al: Hypoxia promotes expansion of the CD133-positive glioma stem cells through activation of HIF-1alpha. Oncogene 28: 3949-3959, 2009.

22. Lum JJ, Bui T, Gruber M, Gordan JD, DeBerardinis RJ, Covello KL, Simon MC and Thompson CB: The transcription factor HIF-1alpha plays a critical role in the growth factordependent regulation of both aerobic and anaerobic glycolysis. Genes Dev 21: 1037-1049, 2007.

23. García-Maceira P and Mateo J: Silibinin inhibits hypoxiainducible factor-1alpha and mTOR/ p70S6K/4E-BP1 signalling pathway in human cervical and hepatoma cancer cells: Implications for anticancer therapy. Oncogene 28: 313-324, 2009.

This work is licensed under a Creative Commons Attribution-NonCommercial-NoDerivatives 4.0 International (CC BY-NC-ND 4.0) License. 